\title{
Depicting Chemistry Teachers' Perception of Laboratory Environment and Teaching Satisfaction
}

\begin{abstract}
Fitria Fatichatul Hidayah, Department of Chemistry Education, Universitas Muhammadiyah Semarang, Indonesia, fitriafatichatul@unimus.ac.id, ORCID: 0000-0003-3821-7726
\end{abstract}

Muhamad Imaduddin, Institut Agama Islam Negeri Kudus, Indonesia, imad@iainkudus.ac.id, ORCID:00000002-3619-9985

Eko Yuliyanto, Department of Chemistry Education, Universitas Muhammadiyah Semarang, Indonesia, ekoyuliyanto@unimus.ac.id, ORCID:0000-0003-1183-5014

Supawan Tantayanon, Department of Chemistry, Faculty of Science, Chulalongkorn University, Thailand, Supawan.T@chula.ac.th,ORCID:0000-0003-0011-4684

Gunawan, Department of Chemistry Diponegoro University, Indonesia, gunawan@live.undip.ac.id. ORCID: 0000-0001-6305-7301

Muhammad Cholid Djunaidi, Department of Chemistry Diponegoro University, Indonesia, choliddjunaidi@live.undip.ac.id, ORCID: 0000-0003-2594-5062

\begin{abstract}
The design of laboratories in many schools does not meet the pedagogical needs of laboratories. Traditional learning methods not only dominate the learning process in the classroom but also practical learning activities. This study aims (1) to depict perceptions on psychosocial aspects that include student cohesiveness, open-endedness, classroom integration, rule clarity, and material environment; (2) to uncover the relationship between laboratory learning environments and the chemistry teachers' satisfaction of teaching. The research method used a case study. It was carried out on a group of teachers who are members of a working group of high school chemistry teachers in the Jepara Regency, Central Java Province, Indonesia. The sampling method is convenience sampling. The sample used was teachers who were members of a working group of teachers who were active in the study area. The sample consisted of twenty-six chemistry subject teachers consisting of 9 males and 17 females. The research instrument is a questionnaire that includes three parts. Perceptions of expectations and reality are measured through items that include teaching satisfaction and psychosocial aspects which consist of (1) Student Cohesiveness (SC); (2) Open-endedness (OE); (3) Classroom Integration (CI); (4) Rule Clarity (RC); (5) Material Environment (ME). The conditions of perception of expectations and reality have been described by a significant decrease in four scales, namely SC, OE, RC, and ME. The four scale laboratory environments have a significant correlation with teacher satisfaction in teaching chemistry in the laboratory. The aspect of CI did not experience a significant decrease and did not provide a significant correlation with teacher's teaching satisfaction. Correlation analysis shows that teachers' satisfaction in teaching is significantly influenced by the learning environment $(83.2 \%)$, in this case, the greatest influence in the sequence is the rule clarity (83.9\%), student cohesiveness $(70.3 \%)$, material environment (69.8\%), open-endedness (65.5\%), and classroom integration (38.0\%).
\end{abstract}

Keywords: Chemistry teachers' perception; Laboratory environment; Psychosocial aspects; Teaching satisfaction

$\begin{array}{lll}\text { Received: } 14.11 .2020 & \text { Accepted: 11.12.2020 } & \text { Published: 20.01.2021 }\end{array}$

\section{INTRODUCTION}

A lot of literature has described various kinds of positive impacts given by laboratory activities in science learning. The involvement of students in laboratory activities has encouraged students' understanding of scientific concepts, problem-solving skills, process skills, and attitudes towards science (Colthorpe et al., 2017; Imaduddin \& Hidayah, 2019; Merritt et al., 1993; Rohaeti \& Prodjosantoso, 2018; Uzezi \& Zainab, 2017; Zakaria et al., 2012). Laboratory activities have the potential to increase the active participation of students in authentic investigations where they can identify problems, design procedures, and infer from the findings of practicum. These scientific activities can give a feeling about how the scientists carry out their work so that later it can influence students' attitudes about scientific endeavors (Chiang \& Lee, 2016; Chiappetta \& Koballa, 2010). Nevertheless, the practicum implementation still faces many obstacles. This includes budget constraints for organizing activities, lack of proper laboratory infrastructure, lack of tool and chemicals, absence of laboratory assistants, time constraints, poor quality 
of practicum holders, and poor laboratory management (Bell \& Bradley, 2012; Bradley, 2001; Rahman et al., 2015; Tsaparlis, 2016).

Tan (2008) showed how laboratory activities are usually only used to clarify and verify theories learned in the classroom. Students follow instructions (recipes) to conduct experiments so that students can practice standard laboratory procedures and complete their activities as part of fulfilling assessment requirements. Students lack the opportunity to conduct authentic scientific inquiry activities. The possible reason for the design of implementing a school science laboratory is the teacher's epistemological view of science (Tsai, 2003). Perspectives on the purpose of work in the laboratory affect the teacher in presenting learning based on laboratory activities. Arzi (2003) explained that the physical characteristics of laboratory learning might influence the way teachers teach in science laboratories. For example, intellectual skills through open and authentic laboratory investigations can be supported by carefully designed laboratory activities with appropriate physical facilities such as greater space and time for group discussions. Innovative science teaching and learning strategies as embraced by educational theories that emphasize active, collaborative, and inquiry learning also require a physical layout that is more than just rows of tables and chairs facing the teacher.

The design of laboratories in many schools in Indonesia does not meet the pedagogical needs of laboratories (Marcella et al., 2018; Rahman et al., 2015). In most Indonesian secondary school science laboratories, tables and chairs are still arranged in a line facing the teacher. This design encourages learning transmission theory that emphasizes learning as a lecture and teacher-centered activity (Brandsford et al., 1999; Imaduddin et al., 2019). Traditional learning methods not only dominate the learning process in the classroom but also practical learning activities (Imaduddin \& Hidayah, 2019; Julien \& Lexis, 2015; Merritt et al., 1993). This traditional learning method not only dominates the learning process in the classroom but also learning in the laboratory. Not much research has focused on physical characteristics that lead to students' environment and learning experiences (Halim et al., 2012). This study wants to reveal the extent to which the physical arrangement of the laboratory hinders or supports the process of learning chemistry in the laboratory by reviewing the psychosocial condition from the teacher's perspective. Psychosocial aspects will be analyzed to see how they affect the satisfaction of chemistry teachers in teaching. Teacher satisfaction in teaching becomes important in achieving the goals of the process of teaching and learning chemistry. This study aims to depict perceptions on psychosocial aspects that include student cohesiveness, open-endedness, classroom integration, rule clarity, and material environment (Ahmad et al., 2012; Fraser \& Griffiths, 1992). The existence of a positive psychosocial environment can foster intellectual activity, improve the quality of social contact, stimulate student learning and development of skills, and prevent the emergence of negative events involving students (Ahmad et al., 2012). Besides, this study will also reveal the relationship between laboratory learning environments and the chemistry teachers' satisfaction of teaching. Through the description that occurs, it can be seen how the teacher's role in applying laboratory activities both to the expected perceptions and the reality that occurs in the environment where the teacher teaches. This study takes the case-setting on a small-scale subject that is in an active working group of chemistry subject teachers. Also, the setting taken is in groups in sub-urban areas in Indonesia. This will be one representation of the general conditions in the group of teachers and school laboratories in Indonesia. The depiction is also carried out in detail by considering aspects of the teacher's experience as well as the level of the level taught by the teacher, as well as the diversity of results in responses to the conditions of laboratory implementation obstacles.

\section{METHODS}

The research method used a case study. Case study research is a form of naturalistic inquiry (Arsenault \& Anderson, 1998; Flick, 2004) on specific phenomena in the context of real-life (Cohen et al., 2007). A case study is carried out in a geographical, organizational, institutional, temporal, and another context that allows boundaries to be drawn around the case. These boundaries can be defined by referring to the characteristics and functions determined by the individuals and groups involved (Hitchcock \& Hughes, 1995). The case study was carried out on a group of teachers who are members of a working group of high school chemistry teachers in the district Jepara, Central Java Province. Geographically, this district represents sub-urban areas in Indonesia. A case study seeks to describe certain conditions to uncover the reality in depth (Geertz, 1973) from the participant's life experience.

The sampling method is convenience sampling or often called accidental or opportunity sampling. This sampling involved the selection of the closest individuals to be respondents or those who happened to be available and accessible at the time (Cohen et al., 2007). In this case, the sample used was teachers who were members of a working group of teachers who were active in the study area. The 
sample consisted of twenty-six chemistry subject teachers consisting of 9 males and 17 females. This teacher can be distinguished into a Junior teacher (J) i.e. a teacher who has $\leq 10$ years of experience, while a senior teacher $(S)$ has experienced being a chemistry teacher for more than 10 years. There are 6 junior teachers involved, while there are 20 senior teachers. Also, the identification of teacher characteristics is shown in the teaching task whether at one grade level (SN) or more than one grade level (PL). Teachers' responses related to the constraints of laboratory activity also varied. This is as shown in Figure 1.

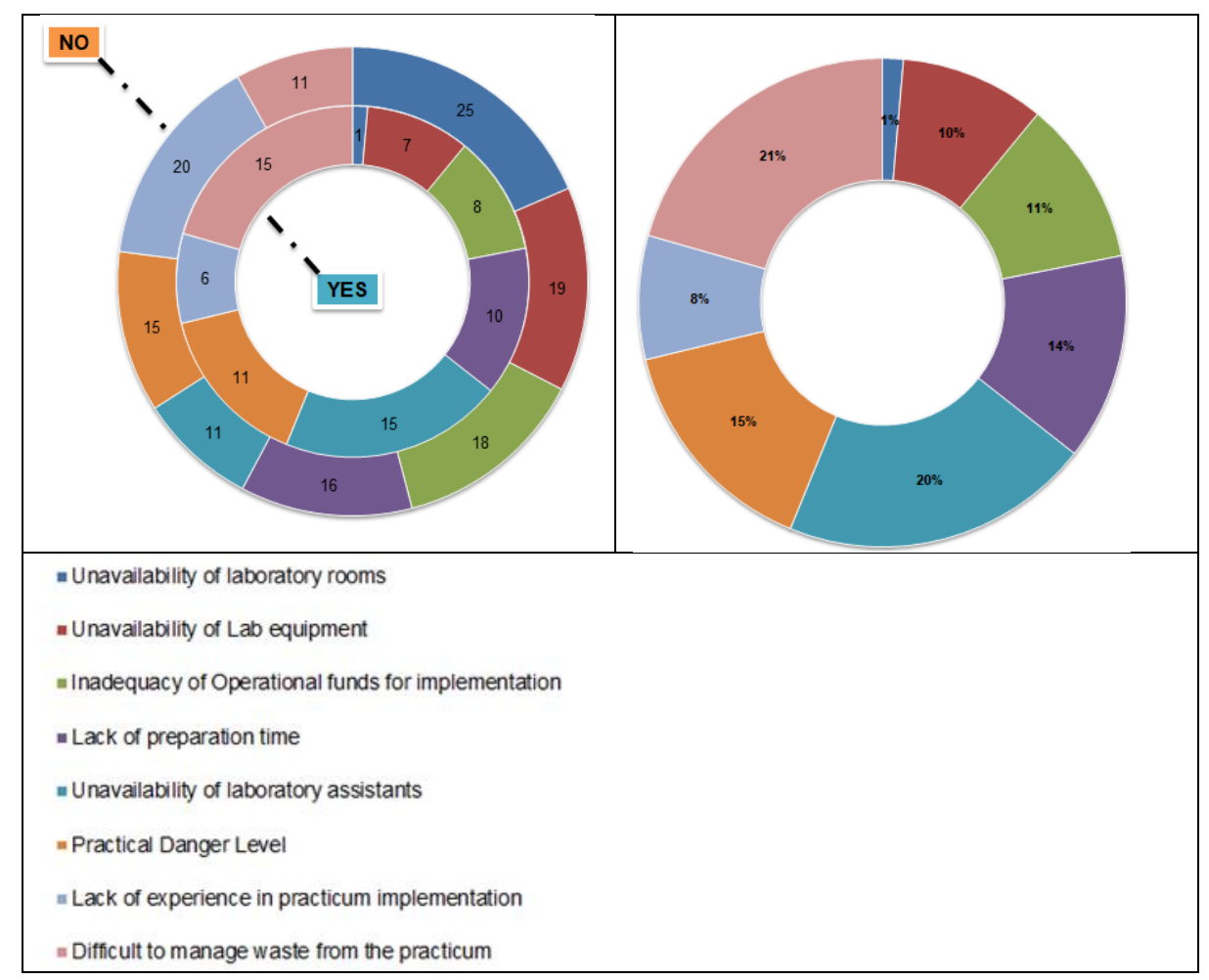
Figure 1. Description of the conditions of teachers' responses to barriers to practicum
implementation $(N=26)$

The research instrument is a questionnaire that includes three parts. The first part is the participant's identity section which is used to see the characteristics of the teacher. The second part is the response to constraints in the implementation of practical learning activities that include 8 items. This section is used to find out the internal conditions of teachers and their institutions as shown in Figure 1. The third part is a section that reveals how perceptions of expectations and reality. Perceptions of expectations and reality are measured through items that include teaching satisfaction and psychosocial aspects which consist of (1) Student Cohesiveness (SC); (2) Open-endedness (OE); (3) Classroom Integration (CI); (4) Rule Clarity (RC); (5) Material Environment (ME). The instrument for measuring laboratory environment was developed in Indonesian by adapting the Science Laboratory Environment Inventory (SLEI) which was originally modified from the domain of science learning in the Test of Related Science Attitudes (TOSRA) (Halim et al., 2012). The original reliability score of this instrument was ranged from 0.70 to 0.83 (Fraser \& McRobbie, 1995). In this study, the instrument is referred to as the Chemistry Laboratory Environment Inventory (CLEI). Each aspect has four items both in the expectations and reality aspects. Thus, in the condition of expectation and reality, each item is revealed with 24 items. Participants are asked to respond to the statements with a five-point scale. Scores of 5, 4, 3, 2, and 1 indicate perceptions of "strongly agree", "agree", "neutral", "disagree", and "strongly disagree". The scale description and sample items are shown in Table 1.

Table 1. Description of the scale and sample of items on the research instrument

\begin{tabular}{|c|c|c|}
\hline Scale & Description & Sample Item \\
\hline $\begin{array}{l}\text { Student } \\
\text { Cohesiveness } \\
\text { (SC) }\end{array}$ & $\begin{array}{l}\text { The extent to which students } \\
\text { help each other, work together } \\
\text { and support one another in } \\
\text { chemistry-based learning. }\end{array}$ & $\begin{array}{l}\text { 1. Students should work together to plan and } \\
\text { prepare chemistry lab tools and materials. } \\
\text { (Expectation) } \\
\text { 2. Students have collaborated in planning and }\end{array}$ \\
\hline
\end{tabular}




\begin{tabular}{|c|c|c|}
\hline Scale & Description & Sample Item \\
\hline & & $\begin{array}{l}\text { preparing chemistry lab tools and materials. } \\
\text { (Reality) }\end{array}$ \\
\hline $\begin{array}{l}\text { Open- } \\
\text { endedness } \\
\text { (OE) }\end{array}$ & $\begin{array}{l}\text { The extent to which learning in } \\
\text { the laboratory emphasizes the } \\
\text { open-ended and divergent } \\
\text { approaches. }\end{array}$ & $\begin{array}{l}\text { 1. Students should be able to modify the work } \\
\text { practices that have been obtained from the } \\
\text { teacher. (Expectation) } \\
\text { 2. Students are allowed to modify the way the } \\
\text { practicum has been obtained from the teacher. } \\
\text { (Reality) }\end{array}$ \\
\hline $\begin{array}{l}\text { Classroom } \\
\text { Integration } \\
\text { (CI) }\end{array}$ & $\begin{array}{l}\text { The extent to which activities in } \\
\text { the laboratory are integrated } \\
\text { with theoretical learning in the } \\
\text { classroom }\end{array}$ & $\begin{array}{l}\text { 1. Student activities done in class should be in line } \\
\text { with activities done in the laboratory. } \\
\text { (Expectation) } \\
\text { 2. Student activities done in class are in line with } \\
\text { activities done in the laboratory. (Reality) }\end{array}$ \\
\hline $\begin{array}{ll}\text { Rule } & \text { Clarity } \\
\text { (RC) } & \end{array}$ & $\begin{array}{l}\text { The extent to which clarity of } \\
\text { rules in guiding behavior in the } \\
\text { laboratory }\end{array}$ & $\begin{array}{l}\text { 1. The laboratory should have clear rules for the } \\
\text { implementation of the student chemistry } \\
\text { practicum. (Expectation). } \\
\text { 2. The laboratory has clear rules for the } \\
\text { implementation of student chemistry } \\
\text { practicum. (Reality) }\end{array}$ \\
\hline $\begin{array}{l}\text { Material } \\
\text { Environment } \\
\text { (ME) }\end{array}$ & $\begin{array}{l}\text { The extent of the adequacy of } \\
\text { equipment and materials in the } \\
\text { laboratory }\end{array}$ & $\begin{array}{l}\text { 1. The storage of chemicals should be following } \\
\text { procedures for material characteristics and } \\
\text { safety. (Expectation) } \\
\text { 2. Overall chemical storage is following the } \\
\text { procedure's material characteristics and safety. } \\
\text { (Reality) }\end{array}$ \\
\hline $\begin{array}{l}\text { Teaching } \\
\text { Satisfaction } \\
\text { (TS) }\end{array}$ & $\begin{array}{l}\text { The extent to which teachers are } \\
\text { satisfied with learning and } \\
\text { teaching activities in the } \\
\text { laboratory or practicum }\end{array}$ & $\begin{array}{l}\text { 1. I hope I enjoy teaching with practical methods. } \\
\text { (Expectation) } \\
\text { 2. I feel more like teaching with practical methods } \\
\text { rather than classroom learning. (Reality) }\end{array}$ \\
\hline
\end{tabular}

Validity and reliability are measured through the Rasch model analysis by considering the point measure correlation coefficient (PTMEA CORR). If the PTMEA CORR value is high, then an item can distinguish conditions between respondents (Fitri, 2017). A negative or zero value indicates the interwoven response for an item or respondent is contrary to the variable or construct (Linacre, 2020). Reliability is demonstrated through separation reliability which includes person reliability and item reliability, as well as Cronbach Alpha (Sumintono \& Widhiarso, 2013). The result of instrument analysis showed validity and reliability which can be used to measure the conditions of perception of laboratory learning environments and teaching satisfaction. This is as shown in Table 2.

Table 2. Results of Validity and Reliability Analysis using Rasch Model analysis on research instruments

\begin{tabular}{|l|l|l|l|l|l|l|}
\hline \multirow{2}{*}{ Aspects } & \multicolumn{2}{|l|}{ Validity } & Reliability & \multicolumn{2}{l|}{} \\
\cline { 2 - 7 } & $\begin{array}{l}\text { PTMEA } \\
\text { CORR } \\
\text { (min.) }\end{array}$ & $\begin{array}{l}\text { PTMEA } \\
\text { CORR } \\
\text { (max.) }\end{array}$ & Revision & $\begin{array}{l}\text { Person } \\
\text { Reliability }\end{array}$ & $\begin{array}{l}\text { Item } \\
\text { Reliability }\end{array}$ & $\begin{array}{l}\text { Cronbach- } \\
\text { Alpha (KR- } \\
\text { 20) }\end{array}$ \\
\hline Expectation & 0.10 & 0.79 & 0 item & 0.71 & 0.88 & 1.00 \\
\hline Reality & -0.38 & 0.90 & 3 items & 0.86 & 0.71 & 0.89 \\
\hline
\end{tabular}

The Rasch model is used to analyze the responses of 22 teachers out of 26 teachers (according to their completeness and willingness to fill in the instruments of measuring expectations and reality). This analysis obtained a Wright Map of Item and Person to describe the distribution of subject conditions and the distribution of the level of difficulty of the item, in this case, is the difficulty of approving the item. Next, the analysis of changes in expectations and reality conditions is analyzed with descriptive statistics and N-gain so that conditions can be categorized as "high", "medium" or "low" (Hake, 1998). Chemistry teachers' perceptions are categorized into four sections based on the average score per item scale. Categories of perception of laboratory learning environment conditions and teaching satisfaction include the categories of "very weak" (1.00-1.99), "weak" (2.00-2.99), "neutral" (3.00-3.99), "strong" (4.00-5.00). 
Significance of change between expectation and reality was identified by the Wilcoxon Signed Ranks Test analysis. The analysis of the significance of the correlation between the reality of teaching satisfaction and the chemistry laboratory environment (and each component) used Nonparametric Correlations (Spearman's rho).

\section{RESULTS}

\section{Perception of Expectations and Reality on the Conditions of the Laboratory Environment and Teaching Satisfaction}

The results of the analysis using the Rasch Model show a wright map that illustrates the distribution of perceptions of laboratory learning environment conditions and expectations of teaching satisfaction and the reality faced by chemistry teachers. The results of differences in the distribution of person and items are shown in Figure 2. An increasingly upward position means how easier it is for participants to agree on an item. This shows that the higher the perception of expectations and the higher the perception of reality. The top position is the junior teacher (J) who teaches classes more than one level (PL). Through this map, it is known how junior teachers who have high expectations compared to their seniors. Interesting conditions can be seen from the subject 016JPL (i.e. junior teachers who teach more than one grade level) experienced a drastic decline in perceptions of expectations and reality.

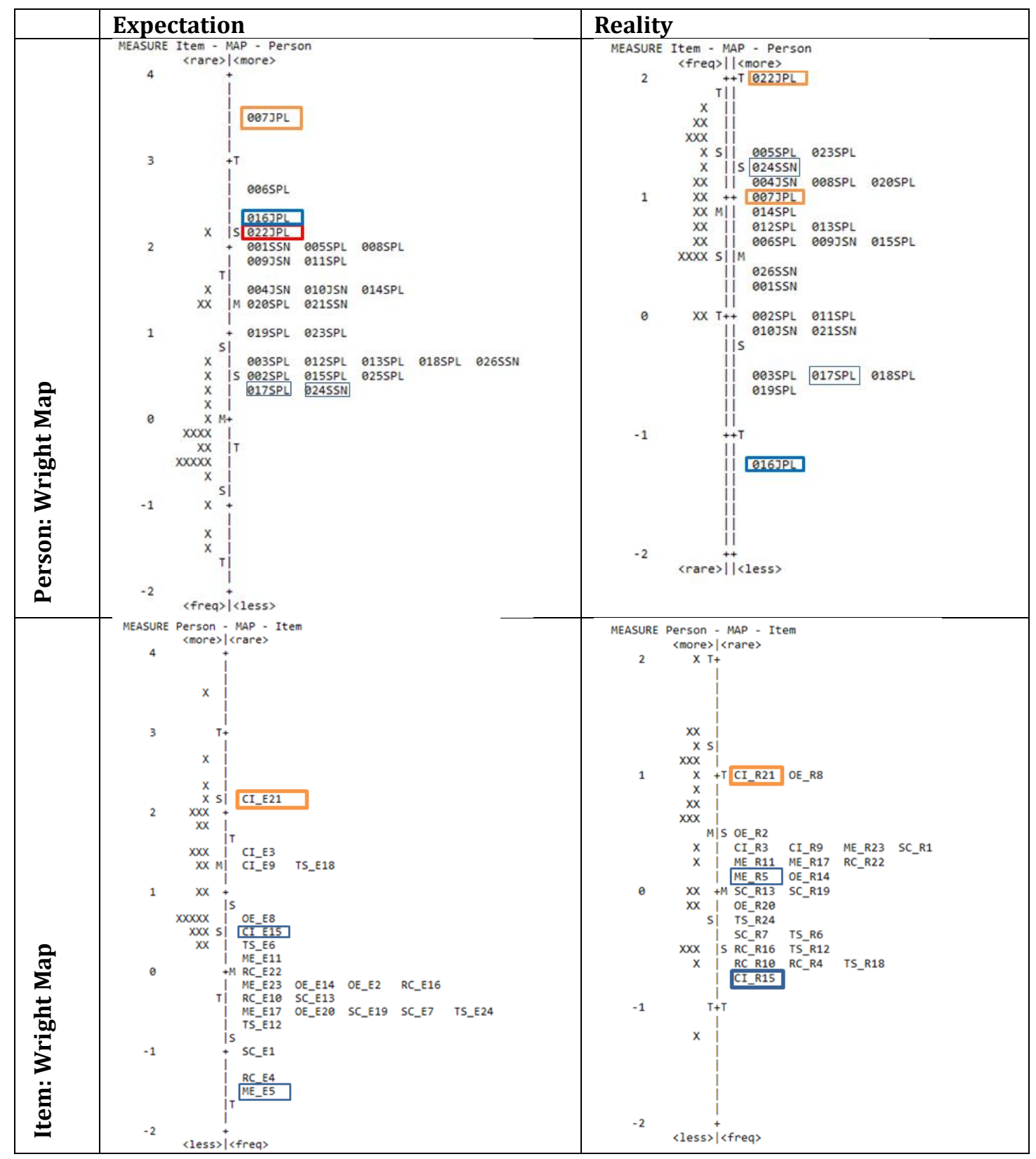


Figure 2. Differences in Mapping of Item and Person that Demonstrate the Expectations and Realities of The Laboratory Environment and Teaching Satisfaction

In mapping expectations and reality scale items, the most difficult item agreed upon by the teacher was on the Classroom Integration scale (CI_21). The most difficult item to agree on is the condition in which laboratory activity is considered not only as a complement to the theory obtained in the classroom. This shows that practicum is still often considered as a complementary activity. Nonetheless, CI_15 which shows the conditions that laboratory activities are arranged based on theoretical material taught in class is the most easily agreed upon the item in reality conditions. What can be observed is also related to the environmental conditions of tools and materials (material environment, ME). Seen how the decline in expectations and reality of teacher perception. In reality conditions, it can be understood that the openendedness approach is difficult to implement in laboratory learning. Students are rarely allowed to design and implement practicums that are appropriate for the construction of student understanding (OE_R8).

\section{Relationship of the Conditions of the Laboratory Environment and Teaching Satisfaction}

The average score on the perceptions of expectations and reality of each component of the laboratory environment and the teaching satisfaction is shown in Table 3. Besides, we can find out how each of the categories of perception changed from strong (yellow box) to neutral perception (blue box). The N-gain component shows the level of change that occurs in each aspect of the perception of the laboratory environment and teaching satisfaction. Significant differences that occur in expectations and reality can be known from the results of tests that produce p-values $(<0.05)$. Spearman's rho correlation coefficient shows the correlation of perceptions of the reality of teaching satisfaction with the laboratory environment.

Table 3. Analysis of Expectation and Reality Conditions in the Laboratory Environment and the Teaching Satisfaction of Chemistry Teachers

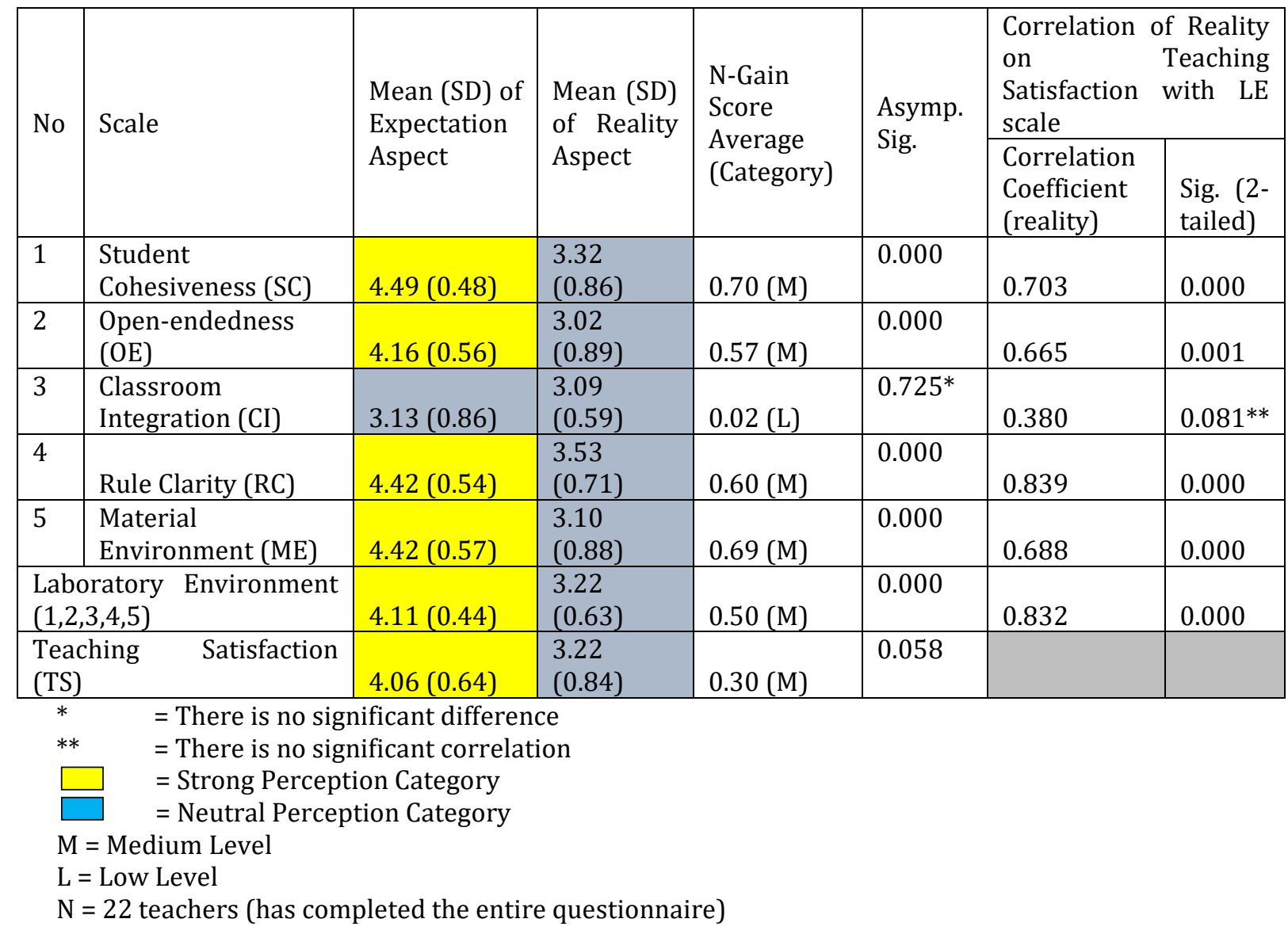

It is known that chemistry teachers have high expectations in the laboratory environment specifically on the aspects of SC, OE, RC, and ME (Table 3.). The expectations of $\mathrm{CI}$ are in the neutral perception category. Also, expectations of teaching satisfaction are at a strong level. However, in reality, all aspects of the scale show a perception of neutral conditions. This shows a decrease in the condition of 
perception of initial expectations with the existing reality. This is illustrated in Figure 3. The highest teacher expectations are on the SC scale while the lowest is on the CI scale. The perception of the reality of the laboratory environment is highest on the $\mathrm{RC}$ scale, while the lowest is on the $\mathrm{OE}$ scale.

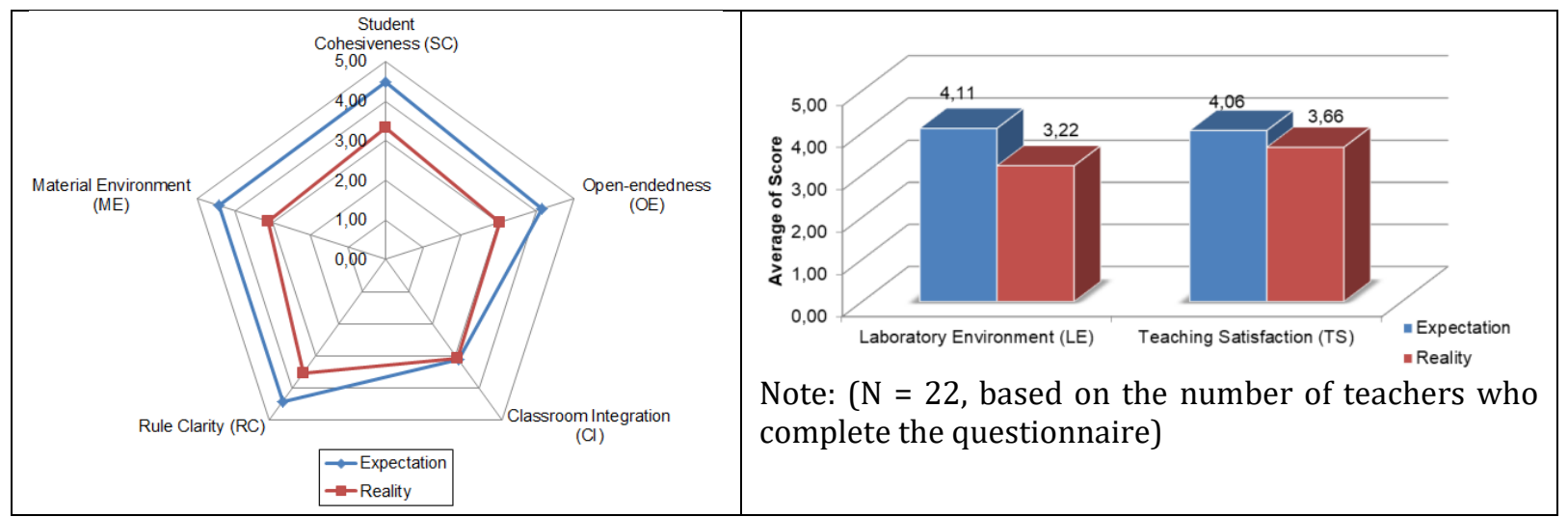

Figure 3. Changes in perception between expectations and reality in every aspect of the laboratory learning environment and teaching satisfaction

Declining conditions indicate conditions at the Medium level in all aspects except for the CI compound which is still at a low level. The highest decrease in conditions is on the SC \& ME scale. The significance of the difference occurs at each scale except at the CI scale. There is a significant correlation between teacher teaching satisfaction with the laboratory environment, which means the better the condition of the laboratory environment, the condition of teaching satisfaction is also affected. The RC scale has the strongest correlation compared to other components, while the CI scale shows no significant correlation with the teaching satisfaction of chemistry teachers.

\section{DISCUSSION}

Case studies in the chemistry teacher group studied showed that there were significant differences between the expected conditions and the reality that occurred in the laboratory environment where the teacher was assigned, as well as the teaching satisfaction of chemistry teachers. The laboratory learning environment includes teacher perceptions on the psychosocial aspects faced including student cohesiveness, open-endedness, classroom integration, rule clarity, and material environment. Teaching satisfaction, in this case, is seen from the teacher's feelings in carrying out the practicum. What was revealed was related to whether the teacher was satisfied and thought that it was carried out supporting student chemistry learning, whether the teacher enjoyed the learning process based on practical activities, whether the teacher was satisfied with the support of tools and materials for practicum activities, and whether the teacher was interested in the planning, implementation, and evaluating practicum activities. The decline in expectations and reality of teaching satisfaction is in line with the decline in perceptions of expectations and the reality of the chemical laboratory environment. The teacher perceived the existing laboratory learning environment as not supporting student learning experiences, such as the lack of opportunities for students to work together during practical activities, the lack of creative activities in practice that is open, unclear rules, or lack of material support tools and materials available (Halim et al., 2012; Tsai, 2003; Wong \& Fraser, 1996). The teacher seems to have perceived conditions that are better than reality (Halim et al., 2012). In this case, junior teachers have higher average expectations and conditions of expectation than senior teachers. Junior teachers are still learning about the best ways to teach and how teaching supports their career development (Md Yunus et al., 2020).

The integration of practical and theoretical classes is the most difficult to agree. This implies that the teachers need to understand more deeply that laboratory activities are not merely complementary but are an effort to construct students' chemical understanding. Lee \& Fraser (2002) showed the teacher's assumption that laboratory activities are seen as an additional learning theory in the classroom. It should be understood that laboratory activities have a certain and crucial role in the science curriculum (Hofstein \& Mamlok-Naaman, 2007), especially chemistry and many research studies showed that there are various benefits by involving students in laboratory activities (Hegarty-Hazel, 1990; Hunter et al., 2000; Mamlok-Naaman \& Barnea, 2012; Uzezi \& Zainab, 2017; Worley et al., 2019). From various reviews, although the laboratory has been given a special role in science education (chemistry), some 
studies have also failed to show a simple relationship between laboratory experience and student learning. Hodson (1993) stated that practicum activities often do not have clear goals and only emphasize the activities carried out by students in the laboratory, so the work is considered unproductive and confusing. Laboratory activities are interesting as a way of learning where at the same time there is a process of building knowledge and scientific activities (Fraser \& McRobbie, 1995; Tobin, 1990). However, Tobin (1990) suggested the need for student opportunities to manipulate tools and materials to construct knowledge related to scientific phenomena and concepts.

The teachers are less able to implement an open-endedness approach that gives students a great opportunity through an open inquiry process in practicum activities. Teachers are less satisfied with their current or actual school laboratories in terms of having the opportunity to do more laboratory work through open inquiry (Halim et al., 2012). The low level of open-endedness in the science laboratory environment was also reported in previous studies in various countries (Ahmad et al., 2012; Berg et al., 2003; Fraser \& McRobbie, 1995; Halim et al., 2012; Lee \& Fraser, 2002; Rahman et al., 2015). Current laboratory classes are usually very coordinated with theoretical classes. This may be because laboratory classes are only adapted to encourage students to verify what they have learned in class theory (Ahmad et al., 2012; Fraser \& Griffiths, 1992; Özkan, 2012). Laboratory activities are only to confirm the theories learned in class and do not give students the freedom to generate their own ideas and opinions (Tan, 2008; Tsai, 2003). The findings of this study are interesting because they show how the opportunity to take a laboratory environmental management policy in the case of the chemistry teacher working group. Teachers 'efforts in presenting open-endedness in their learning are due to the fear of lack of time, the material on students' final tests, as well as the required skills for practicum exams. These are the findings of the teacher's priority to achieve the expected value in students (Lee \& Fraser, 2002).

Identifying and minimizing the gap between the reality learning environment and the expectations felt by the teacher will help improve science teaching and learning (Fraser \& McRobbie, 1995; Halim et al., 2012; Lunetta et al., 2007; Tsai, 2003; Wong \& Fraser, 1997), including chemistry teaching. The teacher will then realize their role in creating a conducive learning environment (Abdullah et al., 2009) which then affects the effectiveness of teaching and learning. Conditions where fewer gaps between the reality faced and expectations expected by the teacher can help improve student learning outcomes on cognitive aspects and attitudes (Fraser, 1994). Correlation analysis shows that teachers' satisfaction in teaching is significantly influenced by the learning environment (83.2\%), in this case, the greatest influence in the sequence is the rule clarity (83.9\%), student cohesiveness $(70.3 \%)$, material environment (69.8\%), open-endedness (65.5\%), and classroom integration (38.0\%).

Teaching satisfaction is crucial because it can improve the quality of positive attitudes in teaching (Akkilic \& Semeric, 2005) so that it can determine the success of a program or educational experience (Askar et al., 2008). The idea of teaching satisfaction is based on the teacher's view that the purpose of laboratory activities is to students produce a product output of activities (Tsai, 2003) making a positivist oriented view (Halim et al., 2012). This condition reflects the lack of understanding of the teacher about the importance of the process of discussion in groups and between groups of students to carry out the process of inquiry openly. The open-endedness scale (OE) shows the lowest average score compared to other scales. It is not surprising if the concept of teacher authority in the classroom is still firmly held, this is also shown by the clarity of the rules, as well as how the concept of integrating class theory leads to the practice as complementary activities learning theory, not as the core of knowledge discovery activities.

\section{CONCLUSION}

The conditions of perception of expectations and reality have been described by a significant decrease in four scales, namely Student Cohesiveness (SC), Open-endedness (OE), Rule Clarity (RC), and Material Environment (ME). The four scale laboratory environments have a significant correlation with teacher satisfaction in teaching chemistry in the laboratory. The aspect of Classroom Integration (CI) did not experience a significant decrease and did not provide a significant correlation with teacher teaching activities.

This study reveals how the implications in the development of chemistry teacher professionalism and how to layout both physically and conceptually design student learning. Teacher's perception of the condition of the laboratory environment in the expectation and reality becomes an indicator of the need for the possibility of laboratory environment management. Also, the chemistry teacher's epistemology view on the implementation of practical activities in the laboratory needs to be handled seriously and formally in pre-service programs as well as in-service teacher training. Teachers' views of the nature of science (chemistry) will affect their organizations in making policies related to the laboratory. 
The process of designing a laboratory environment needs to be carefully designed both physically in the laboratory and the conditions of the design and approach of laboratory learning. Appropriate design and implementation are expected to increase teacher satisfaction in teaching chemistry. The limitations of material tools and materials can be cleverly overcome by using an innovative approach that still presents an inquiry process. Further research needs to be carried out to implement approaches that can facilitate teachers in optimizing the chemistry learning process in the laboratory. One alternative that might be able to facilitate a variety of laboratory conditions at the teacher's institution, in this case, is the small-scale chemistry lab approach (Imaduddin et al., 2020). Further research needs to be carried out to see how this implementation can influence teachers' perceptions of teaching satisfaction from the psychosocial environment that is presented in small-scale chemistry learning.

\section{ACKNOWLEDGEMENTS}

We would like to thank the financial support from Ministry of Research and Technology/National Research and Innovation Agency of the Republic of Indonesia (Kementerian Riset dan Teknologi/ Badan Riset dan Inovasi Nasional) through Higher Education Collaboration Research (PKPT) Scheme. We would also like to thank all those who assisted in collecting research data.

\section{REFERENCES}

Abdullah, M. M., Uli, J., \& Parasuraman, B. (2009). Job satisfaction among secondary school teachers. Jurnal Kemanusiaan, 13, 11-18.

Ahmad, C. N. C., Osman, K., \& Halim, L. (2012). Relationship Between Physical and Psychosocial Aspects in Science Laboratory Learning Environment. Procedia - Social and Behavioral Sciences, 46, 1500-1505. https://doi.org/10.1016/j.sbspro.2012.05.329

Akkilic, M. E., \& Semeric, C. (2005). The measurement of customer's satisfaction in education services marketing. Pakistan Journal of Social Science, 3(9), 997-1001.

Arsenault, N., \& Anderson, G. (1998). Qualitative research. In G. Anderson \& N. Arsenault (Eds.), Fundamentals of Educational Research (second edition) (pp. 119-35). RoutledgeFalmer.

Arzi, H. (2003). Enhancing science education laboratory environments: More than walls, benches and widgets. In B. J. Fraser \& K. G. Tobin (Eds.), International Handbook of Science Education. Kluwer Academic Publishers.

Askar, P., Altun, A., \& Ilgaz, H. (2008). Learner Satisfaction on Blended Learning. E-Leader Krakow.

Bell, B., \& Bradley, J. (2012). Microchemistry in Africa A Reassessment. African Journal of Chemical Education, 2(1), 10-22.

Berg, C. A. R., Bergendahl, V. C. B., Lundberg, B. K. S., \& Tibell, L. A. E. (2003). Benefiting from an openended experiment? A comparison of attitudes to, and outcomes of, an expository versus an openinquiry version of the same experiment. International Journal of Science Education, 25(3), 351-372.

Bradley, J. D. (2001). UNESCO/IUPAC-CTC Global Program in Microchemistry. Pure and Applied Chemistry, 73(7), 1215-1219. https://doi.org/10.1351/pac200173071215

Brandsford, J., Brown, A. L., \& Cocking, R. R. (1999). How people learn: Brain, mind, experience and school. National Academy Press.

Chiang, C. L., \& Lee, H. (2016). The Effect of Project-Based Learning on Learning Motivation and ProblemSolving Ability of Vocational High School Students. International Journal of Information and Education Technology, 6(9), 709-712. https://doi.org/10.7763/IJIET.2016.V6.779

Chiappetta, E. L., \& Koballa, T. R. (2010). Science Instruction in the Middle and Secondary Schools: Developing Fundamental Knowledge and Skills (7th ed.). Pearson Education Inc.

Cohen, L., Manion, L., \& Morrison, K. (2007). Research Methods in Education (Sixth Edit). Routledge.

Colthorpe, K., Mehari Abraha, H., Zimbardi, K., Ainscough, L., Spiers, J. G., Chen, H.-J. C., \& Lavidis, N. A. (2017). Assessing students' ability to critically evaluate evidence in an inquiry-based undergraduate laboratory course. Advances in Physiology Education, 41(1), 154-162. https://doi.org/10.1152/advan.00118.2016

Fitri, F. (2017). Analisis Validitas dan Reliabilitas Instrumen Kinerja Akuntan Menggunakan Pendekatan Rasch Model. Jurnal Ilmiah Akuntansi Peradaban, 3(1), 34-45.

Flick, U. (2004). Design and process in qualitative research. In U. Flick, E. von Kardoff, \& I. Steinke (Eds.), $A$ Companion to Qualitative Research (pp. 146-52). Sage.

Fraser, B.J. (1994). Classroom and school climate. In D. Gabel (Ed.), Handbook of research on science teaching and learning (pp. 493-541). Macmillan. 
Fraser, Barry J., \& Griffiths, A. K. (1992). Psychosocial Environment of Science Laboratory Classrooms in Canadian Schools and Universities. Canadian Journal of Education / Revue Canadienne de l'éducation, 17(4), 391. https://doi.org/10.2307/1495436

Fraser, Barry J, \& McRobbie, C. J. (1995). Science Laboratory Classroom Environments at Schools and Universities: A Cross-National Study. Evaluation: An International Journal on Theory and Practice, 1(4), 289-317. https://doi.org/10.1080/1380361950010401

Geertz, C. (1973). Thick description: towards an interpretive theory of culture. In C. Geertz (Ed.), The Interpretation of Cultures. Basic Books.

Hake, R. R. (1998). Interactive-engagement versus traditional methods: A six-thousand-student survey of mechanics test data for introductory physics courses. American Journal of Physics, 66(1), 64-74. https://doi.org/10.1119/1.18809

Halim, L., Che Ahmad, C. N., Syed Abdullah, S. I. S., \& Subahan Mohd Meerah, T. (2012). Teachers' perception of science laboratory learning environment and its relationship to teachers' satisfaction. International Journal of Learning, 18(8), 67-78.

Hegarty-Hazel, E. (1990). The Student Laboratory and the Science Curriculum. Routledge.

Hitchcock, G., \& Hughes, D. (1995). Research and the Teacher (second edi). Routledge.

Hodson, D. (1993). Re-thinking old ways: Towards a more critical approach to practical work in school science. Studies in Science Education, 22(1), 85-142. https://doi.org/10.1080/03057269308560022

Hofstein, A., \& Mamlok-Naaman, R. (2007). The laboratory in science education: The state of the art. Chemistry Education Research and Practice, 8(2), 105-107. https://doi.org/10.1039/B7RP90003A

Hunter, C., Wardell, S., \& Wilkins, H. (2000). Introducing first-year students to some skills of investigation in laboratory work. University Chemistry Education, 4, 12-15.

Imaduddin, M., \& Hidayah, F. F. (2019). Redesigning Laboratories for Pre-service Chemistry Teachers: From Cookbook Experiments to Inquiry-Based Science, Environment, Technology, and Society Approach. Journal of Turkish Science Education, 16(4), 489-507. https://doi.org/10.36681/tused.2020.3

Imaduddin, M., Tantayanon, S., Zuhaida, A., \& Hidayah, F. F. (2020). Pre-service Science Teachers' Impressions on The Implementation of Small-Scale Chemistry Practicum. Thabiea: Journal of Natural Science Teaching, 3(2), 162. https://doi.org/10.21043/thabiea.v3i2.8893

Imaduddin, M., Zuhaida, A., \& Hidayah, F. F. (2019). Pre-service science teachers' images about their past and future classrooms: Scratches from Indonesian teacher training program at Islamic university. Journal for the Education of Gifted Young Scientists, 7(3), 459-480. https://doi.org/10.17478/jegys.549257

Julien, B. L., \& Lexis, L. A. (2015). Transformation of cookbook practicals into inquiry oriented learning. International Journal of Innovation in Science and Mathematics Education, 23(5), 32-51.

Lee, S., \& Fraser, B. (2002). Laboratory Classroom Environments in Korean High Schools. The Annual Meeting of the American Educational Research Association, New Orleans, April 2002. http://eric.ed.gov/?id=ED464831

Linacre, J. M. (2020). A User's guide to WINSTEPS Ministeps: Rasch- model Computer Program Program Manual 4.5.3. https://www.winsteps.com/tutorials.htm

Lunetta, V. N., Hofstein, A., \& Clough, M. P. (2007). Learning and teaching in the school science laboratory: An analysis of research, theory, and practice. In S. K. Abell \& N. G. Lederman (Eds.), Handbook of research on science education (pp. 393-441). Erlbaum.

Mamlok-Naaman, R., \& Barnea, N. (2012). Laboratory activities in Israel. Eurasia Journal of Mathematics, Science and Technology Education, 8(1), 49-57. https://doi.org/10.12973/eurasia.2012.816a

Marcella, Z., Susanti, N., \& Dani, R. (2018). Analisis Hambatan Pelaksanaan Praktikum IPA Terpadu di SMPN 17 dan SMPN 19 Kota Jambi. Edufisika: Jurnal Pendidikan Fisika, 3(2), 41-48.

Md Yunus, A. S., Esa, N., Zakaria, M. H., Saari, N., Ismail, A., Noordin, N., Cummings, R., Smigiel, H., \& Whitsed, C. (2020). Comparison between the senior and junior academics' perceptions on criteria in measuring teaching effectiveness. Universal Journal of Educational Research, 8(3), 17-30. https://doi.org/10.13189/ujer.2020.081603

Merritt, M. V., Schneider, M. J., \& Darlington, J. A. (1993). Experimental Design in the General Chemistry Laboratory. Journal of Chemical Education, 70(8), 660-662.

Özkan, G. (2012). How Effective Is "Conceptual Change Approach" in Teaching Physics? Journal of Educational and Instructional Studies in the World, 2(2), 182-190.

Rahman, D., Adlim, A., \& Mustanir, M. (2015). Analisis Kendala dan Alternatif Solusi terhadap Pelaksanaan Praktikum Kimia pada SLTA Negeri Kabupaten Aceh Besar. Jurnal Pendidikan Sains Indonesia, 03(02), 1-13.

Rohaeti, E., \& Prodjosantoso, A. K. (2018). Undergraduate students' science process skills in terms of 
some variables: A perspective from Indonesia. Journal of Baltic Science Education, 17(5), 751-764.

Sumintono, B., \& Widhiarso, W. (2013). Aplikasi Model Rasch untuk Penelitian Ilmu-ilmu Sosial. Tim Komunikata Publishing House.

Tan, A. L. (2008). Tensions in the biology laboratory: What are they? International Journal of Science Education, 30(12), 1661-1676. https://doi.org/10.1080/09500690701564621

Tobin, K. (1990). Research on Science Laboratory Activities: In Pursuit of Better Questions and Answers to Improve Learning. School Science and Mathematics, 90(5), 403-418. https://doi.org/10.1111/j.1949-8594.1990.tb17229.x

Tsai, C. C. (2003). Taiwanese science student's and teachers' perceptions of the laboratory learning environments: Exploring epistemological gaps. International Journal of Science Education, 25(7), 847-860. https://doi.org/10.1080/09500690305031

Tsaparlis, G. (2016). Problems and Solutions in Chemistry Education. Journal of the Turkish Chemical Society Section C: Chemical Education, 1(1), 1-30. https://doi.org/10.1142/7741

Uzezi, J. G., \& Zainab, S. (2017). Effectiveness of Guided-Inquiry Laboratory Experiments on Senior Secondary Schools Students Academic Achievement in Volumetric Analysis. American Journal of Educational Research, 5(7), 717-724. https://doi.org/10.12691/education-5-7-4

Wong, A. F. L., \& Fraser, B. J. (1996). Environment--Attitude Associations in the Chemistry Laboratory Classroom. Research in Science \& Technological Education, 14(1), 91-102. https://doi.org/10.1080/0263514960140107

Wong, A. F. L., \& Fraser, B. J. (1997). Assessment of Chemistry Laboratory Classroom Environments. Asia Pacific Journal of Education, 17(2), 41-58. https://doi.org/10.1080/02188799708547761

Worley, B., Villa, E. M., Gunn, J. M., \& Mattson, B. (2019). Visualizing Dissolution, Ion Mobility, and Precipitation through a Low-Cost, Rapid-Reaction Activity Introducing Microscale Precipitation Chemistry. Journal of Chemical Education, 96(5), 951-954. https://doi.org/10.1021/acs.jchemed.8b00563

Zakaria, Z., Latip, J., \& Tantayanon, S. (2012). Organic Chemistry Practices for Undergraduates using a Small Lab Kit. Procedia - Social and Behavioral Sciences, 59, 508-514. https://doi.org/10.1016/j.sbspro.2012.09.307 